\title{
Good Governance Dalam Perspektif Islam (Pendekatan Ushul Fikih: Teori Pertingkatan Norma)
}

\author{
Joko Setyono
}

Email: setyo_belsa17@yahoo.com

UIN Sunan Kalijaga Yogyakarta

\begin{abstract}
This article aims to analyze good governance in Islamic perspective with the classical norm levels theory and ushul fiqh approach. This article may contribute to the understanding that Islamic law is able to answer the challenge of modernity namely continuity and change. In this context, ushul fiqh still consider the reality of society which give humanistic and authoritative (not authoritarian Islamic law) in formulation of Islamic Law.
\end{abstract}

\begin{abstract}
Abstrak
Artikel ini bertujuan untuk menganalisis good governance dalam perspektif Islam dengan pendekatan ushul fikih tentang teori pertingkatan norma. Kajian good governance dapat diintegrasikan dengan ushul fiqh, yaitu dengan menggali nilai-nilai filosofis (the theory values) norma dalam hukum Islam. Tulisan ini dapat memberikan warna, bahwa hukum Islam (ushul fiqh) selalu berkembang dan mampu menjawab tantangan modernitas yang berkarakter continuity and change. Artinya, ushul fiqh tetap memperhatikan realitas masyarakat (living law), sehingga melahirkan rumusan hukum Islam yang humanis dan otoritatif (bukan otoritarianisme hukum Islam).
\end{abstract}

Kata Kunci:Good Governance, ushul fikih, teori pertingkatan norma

\section{Pendahuluan}

Pemerintahan sebagai suatu kenyataan yang tidak dapat dihindarkan dalam hidup setiap warganegara yang memiliki banyak arti bagi mereka, secara perorangan atau secara bersama-sama. Pemerintah adalah harapan 
dan peluang untuk mewujudkan hidup yang sejahtera dan berdaulat melalui pengelolaan kebebasan dan persamaan yang dimiliki oleh warganegara. Pada sisi lain, pemerintah adalah tantangan dan kendala bagi warganegara terutama ketika pemerintah terjauhkan dari pengalaman etika pemerintahan.

Suatu masyarakat tanpa pemerintahan adalah sebuah kekacauan massal. Di dalam masyarakat manusia beradab, diperlukan lebih banyak peraturan. Diperlukan juga lebih banyak upaya dan kekuatan untuk menjamin bahwa peraturan-peraturan itu ditaati.

Harapan yang ingin diwujudkan oleh setiap warganegara melalui proses pemerintahan adalah berlangsungnya kehidupan secara wajar, dalam semua bidang dan ukuran kehidupan mereka. Pemerintahan pertama-tama diharapkan dapat membentuk kesepakatan warganegara tentang bingkai kepatutan dalam proses kehidupan kolektif warganegara. Dengan demikian, kebutuhan akan kehidupan yang wajar mensyaratkan kewajiban pemerintah untuk membentuk hukum yang adil dan melakukan penegakkan hukum demi rasa keadilan tersebut pada semua warganegara.

Untuk mewujudkan tujuan dan harapan tersebut, maka diperlukan suatu sistem pemerintahan yang baik dan efektif yang sesuai dengan prinsipprinsip bersifat demokratis, konsep pemerintahan yang baik itu disebut dengan good governance.Good governance selalu menarik dan menjadi perhatian oleh para pakar keilmuan, bukan hanya pakar politik, melainkan juga para pakar hukum, ekonomi, manajemen pemerintahan, tata negara, dan bahkan hukum Islam atau ushul fiqh (Anwar, 2007).

Secara ringkas good governance pada umumnya diartikan sebagai tata kelola pemerintahan yang bersih dan baik (good and clean governance), menjadi perhatian karena peran pemerintah (institution) sangat mendominasi dalam berbagai sektor pembangunan negara (Anwar, 2007). Reformasi yang diharapkan sebagai langkah awal untuk membangun good governance pemerintahan yang bersih, transparan, dan akuntabel- masih banyak mengalami hambatan besar. Praktik korupsi, kolusi, dan nepotisme masih banyak terjadi dan masih sangat kental. Secara historis, agama juga mempunyai peran besar dalam mewujudkan civil society untuk mewujudkan (tata kelola) pemerintahan yang baik (good governance) (Suraji, 1998). 
Kata "good" (baik) disini dimaksudkan sebagai mengikuti kaidahkaidah tertentu sesuai dengan prinsip-prinsip dasar good governance atau kalau dipadukan dengan hukum Islam sesuai dengan prinsip-prinsip dasar hukum Islam (al-qiyām al-asāsiyah), dalam hal konteks pendekatan ushul fiqh mempnyai teori pertingkatan norma. Yang menjadi sense of crisis atau pertanyaan mendasar adalah bagaimana penerapan teori pertingkatan norma dalam ushul fiqh dalam membangun konsep good governance dalam hukum Islam?

Oleh karena itu, tema berjudul "Good Governance dalam Perspektif Islam (Tinjauan Ushul Fiqh dari Teori Pertingkatan Norma)" ini lebih diarahkan kepada bagaimana mendayagunakan metode yang ditawarkan dalam ilmu ushul fiqh untuk merumuskan asas-asas hukum Islam untuk merespons berbagai persoalan mutakhir dari segala persoalan, dan di sini secara khusus akan membahas masalah good governance dalam perspektif Islam dengan pendekatan ushul fiqh sebagai landasan epistemologis dan filosofis dalam hukum Islam dengan menjabarkan teori "pertingkatan norma" sebagai aplikasi teori (applied theory) dalam menggali nilai-nilai menuju pelayanan publik (good governance).

Kajian good governance dapat diintegrasikan dengan ushul fiqh, yaitu dengan menggali nilai-nilai filosofis (the theory values) norma dalam hukum Islam sangat penting untuk dikaji. Dalam pembahasan ini, akan dikaji tentang teori pertingkatan norma sebagai pendekatan ushul fikih, selanjutnya membahas tentang pengertian dan konsep good governance dengan mengintegrasikan dengan pendekatan ushul fiqh dan pada bagian akhir akan dibahas tentang good governance perspektif Islam. Tulisan ini dapat memberikan warna, bahwa hukum Islam (ushul fiqh) selalu berkembang dan mampu menjawab tantangan modernitas yang berkarakter continyuty and change (Hallaq, 2004). Artinya, ushul fiqh tetap memperhatikan realitas masyarakat (living law), sehingga melahirkan rumusan hukum Islam yang humanis dan otoritatif (bukan otoritarianisme hukum Islam) (Abdullah, 2004).

\section{PendekatanUshul Fiqh: Teori Pertingkatan Norma}

Sebagai metode penemuan hukum, usul fikih merupakan bagian dari metode penelitian hukum Islam secara umum. Penelitian hukum Islam secara 
keseluruhan dibedakan ke dalam dua bidang, yaitu: Penelitian hukum Islam deskriptif dan penelitian hukum Islam preskriptif. Penelitian hukum Islam deskriptif melihat hukum Islam sebagai suatu fenomena sosial yang berinteraksi dengan gejala-gejala sosial lainnya. Penelitian hukum Islam preskriptif bertujuan menggali norma-norma hukum Islam dalam tataran das sollen, yaitu norma-norma yang dipandang ideal untuk dapat mengatur tingkah laku manusia dan menata kehidupan yang baik. Penelitian hukum Islam dengan metode usul fikih termasuk kedalam bidang penelitian hukum Islam preskriptif, yang bertujuan menemukan norma-norma syariah untuk merespon berbagai permasalahan dari sudut pandang normatif.

Pada era klasik, para ahli hukum Islam sudah membuat pelapisan norma-norma hukum Islam yang terdiri dari dua tingkat, yaitu asas-asas umum (al-ushûl al-kulliyyah) dan peraturan-peraturan hukum konkret (ala\%kam al-far'iyyah). Meskipun waktu itu istilah good governance masih belum terkonsep, tetapi paling tidak, ide-ide nilai dalam filsafat hukum Islam sudah begitu kentalnya. Dalam hal ini, pemahaman konseptual good governance yang mengatakan bahwa nilai yang menjunjung tinggi keinginan at au kehendak rakyat, kemandirian, keadilan, demokrasi, termasuk fungsional pemerintah yang efektif dan efisisen sangat identik dengan pendekatan ushul fiqh yang ditulis dalam buku Syamsul Anwar tentang teori pertingkatan norma dalam hukum Islam, bahwa hukum Islam sesungguhnya terdiri atas norma-norma bernjenjang (berlapis).

Oleh karena itu, menurut Syamsul Anwar, perjenjangan norma hukum Islam tersebut dibuat menjadi tiga jenjang, pertama, norma-norma dasar atau nilai-nilai filosofis (al-qiyām al-asāsiyah) yaitu norma-norma abstrak yang merupakan nilai-nilai dasar hukum Islam. Di dalam al-Qur'an secara harfiah dan secara implisit banyak ditemukan nilai-nilai dasar Islam yang menjadi nilai-nilai dasar hukum Islam. Misalnya kemaslahatan, keadilan, kebebasan, persamaan, persaudaraan, akidah, syura, tasamuh, ajaran-ajaran pokok dalam etika Islam (akhlak). Kedua, norma tengah, yang terletak antara dan sekaligus menjembatani nilai-nilai dasar dengan peraturan hukum konkret. Norma-norma tengah ini dalam ilmu hukum Islam merupakan doktrin-doktrin (asas-asas) umum hukum Islam, dan secara konkretnya dibedakan menjadi dua macam, yaitu asas-asas hukum Islam (an-nazzariyat 
al-fiqhiyyah) dan kaidah-kaidah hukum Islam (al-qawaid al-fiqhiyyah). Ketiga, peraturan-peraturan hukum konkret (al-ahkam al-far'iyyah), yaitu ketentuan-ketentuan syar'i mengenai berbagai kasus hukum (Anwar, 2007).

Gambar 1

\section{Pelapisan norma-norma hukum Islam}

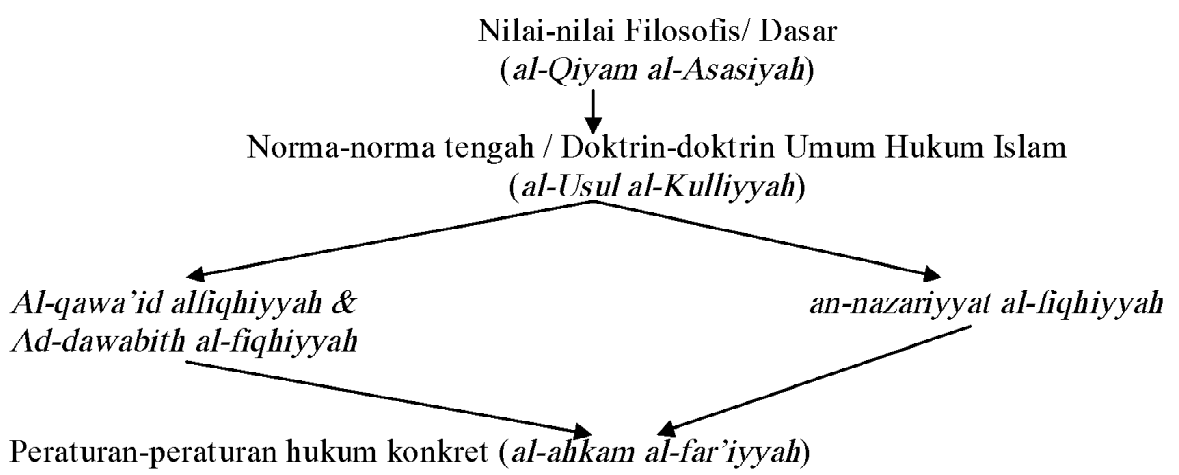

Mengenai teori pertingkatan norma di atas, secara sederhana dapat dijelaskan bahwa teori pertingkatan norma adalah teori yang mencoba menemukan hukum lewat tiga penjenjangan norma, yaitu, pertama, normanorma dasar atau nilai-nilai filosofis (al-qiyām al-asāsiyyah) seperti kemaslahatan, keadilan, kesetaraan. Norma-norma tersebut sebahagian sudah ada berdasarkan fakta-fakta dan sudah diakui. Kedua, norma-norma tengah berupa doktrin-doktrin umum hukum Islam yaitu an-nazariyyah al-fiqhiyyah, ad-dawābith al-fiqhiyyah, dan al-qawā'id al-fiqhiyyah. Ketiga, peraturanperaturan hukum kongkret (al-ahkām al far'iyyah).

Ketiga lapisan norma ini tersusun secara hierarkis di mana norma yang paling abstrak dikongkritisasi menjadi norma yang lebih kongkret. Contoh nilai dasar kemaslahatan dikonkretisasi dalam norma tengah (doktrin umum) berupa kaidah fiqhiyyah yaitu "kesukaran memberi kemudahan". Oleh karena itu, norma-norma tersebut dapat dibagi menjadi tiga, yaitu peraturan-peraturan hukum konkrit, asas-asas umum, dan nilai-nilai dasar (Anwar, 2007). Norma tengah ini dikonkretisasi lagi dalam bentuk peraturan hukum konkret misalnya menyelenggarakan pemerintahan yang baik dengan bertindak adil, transparan, dan akuntabel adalah hukumnya wajib para penyelenggara birokrasi Negara. 
Dengan adanya pemerintahan yang baik diharapkan mampu menjadikan masyarakat sebagai bangsa yang makmur dan sejahtera. Artinya, good governance yang baik adalah Negara yang paling minim kekuasannya dengan mempertimbangkan kepentingan atau kemaslahatan umum (masyarakat). Teori pertingkatan norma ini dapat dijadikan sebagai salah satu pendekatan dalam pengembangan paradigma hukum Islam sebagai paradigma alternatif dengan mengkombinasikannya dengan metode holistik "teori induktif/ integrative" dalam memecahkan persoalan hukum Islam (Anwar, 2007). Teori pertingkatan norma ini dapat dijadikan sebagai salah satu pendekatan dalam pengembangan paradigma hukum Islam sebagai paradigma alternatif dengan mengkombinasikannya dengan metode holistik - teori induktif/integratifdalam memecahkan persoalan hukum Islam (Anwar, 2007).

Dari teori pertingkatan norma ini, dapat diintegrasikan juga dengan teori maqāshid al-syari' 'ah yang juga merupakan nilai-nilai dasar hukum Islam (al-qiyām al-asāsiyyah). Good governance dapat terwujud bila masyarakat dan aparatur pemerintah menjadikan hukum Islam sebagai pedoman perilaku dalam setiap perbuatan dan perilaku kehidupannya, karena prinsip atau nilainilai dasar yang harus dijadikan pegangan dalam penetapan hukum Islam adalah kemaslahatan umum dan norma-norma dasar (nilai-nilai filosofisal-qiyām al-asāsiyyah - melalui penegakan lima prinsip dasar (al-ushūl alkhamsah) dalam teori maqāshid al-syarì'ah yaitu, hifz al-dīn (menjaga agama), hifz al-nafs (menjaga jiwa), hifz al-'aql (menjaga akal), hifz al-nasl (menjaga keturunan), dan hifz al-māl (menjaga harta) (al-Buty, 1997: 27).

Dengan mengaktualisasikan hukum Islam dalam perilaku berbangsa dan bernegara, diharapkan dapat mewujudkan good governance. Maka di bawah ini akan dibahas tentang beberapa hal yang berkaitan dengan kontribusi hukum Islam dalam mewujudkan good governance dan penerapan teori pertingkatan makna dalam pendektan ushul fiqh dalam menggali hakikat (nilai-nilia filosofis) good governance dalam hukum Islam.

Dalam hal ini, makna lain dari nilai-nilai filsafat dan filsafat hukum good governance dalam hukum Islam menjelaskan antara lain menyingkap tentang rahasia-rahasia hukum (asrār al-aḥkām), makna terdalam dalam hukum Islam (deep meaning), hikmah at-tastrì' dan nilai fiolosofisnya, serta menggali nilai-nilai (values) atau norma-norma hukum Islam dalam tataran 
das sollen yang terkandung dalam nilai-nilai good governance, yaitu konsep ideal mengenai tingkah laku manusia dan menata kehidupan bermasyarakat dan bernegara yang baik.

Nilai-nilai tersebut seperti nilai kesetaraan, keadilan, kebebasan, persamaan, persaudaraan, syūrā tasāmuh atau ajaran-ajaran pokok etika Islam (Anwar, 2004).Tent unya menggali dalil-dalil kaitannya dengan pemerintahan yang baik (good governance) dari sisi (maqāshid al-ahkām) (kaidah-kaidah hukum (qawā'id al-ahkām), rahasia-rahasia hukum Islam (asrār al-ahkām), keistimewaan-keistimeawaan hukumIslam (mazāyā al-ahkām) yang kesemunya disebut sebagai hikmah wa falsafatu at-tasyrï' (hikmah dan nilainilai sebuah syari'ah/hukum Islam) (al-Jarjani, 1997: 15-20).

\section{Pengertian Good Governance}

Dalam kamus, istilah "government" dan "governance" seringkali dianggap memiliki arti yang sama yaitu cara menerapkan otoritas dalam suatu organisasi, lembaga atau negara. Government (pemerintahan) juga adalah nama yang diberikan kepada entitas yang menyelenggarakan kekuasaan pemerintahan dalam suatu negara. Governance diartikan sebagai mekanisme, praktek dan tata cara pemerintahan dan warga mengatur sumber daya serta memecahkan masalah masalah publik. Dalam konsep governance, pemerintah hanya menjadi salah satu actor dan tidak selalu menjadi aktor yang menentukan.

Implikasi peran pemerintah sebagai pembangunan maupun penyedia jasa layanan dan infrastruktur akan bergeser menjadi bahan pendorong terciptanya lingkungan yang mampu memfasilitasi pihak lain di komunitas. Governance menunt ut redefinisi peran negara, dan itu berarti adanya redefinisi pada peran warga. Adanya tuntutan yang lebih besar pada warga, antara lain untuk memonitor akuntabilitas pemerintahan itu sendiri (Hetifa 2003: 1-2). Bank Dunia memberikan pengertian bahwa good governance adalah upaya penyelenggaraan manajemen pembangunan negara yang solid dan bertanggung jawab serta sejalan dengan prinsip demokrasi dan pasar yang efisien, penghindaran salah alokasi dana investasi, dan pencegahan korupsi baik secara politik maupun administratif, menjalankan disiplin 
anggaran serta penciptaan legal and political framework bagi tumbuhnya aktivitas usaha dalam rangka mengelola sumberdaya ekonomi dan sosial untuk kepentingan pembangunan dan masyarakat (Anwar, 2007).

Secara konseptual pengertian good dalam istilah good governance mengandung dua pemahaman. Pertama,nilai yang menjunjung tinggi keinginan atau kehendak rakyat serta nilai-nilai yang dapat meningkatkan kemampuan rakyat dalam mencapai tujuan nasional, kemandirian pembangunan yang berkelanjutan dan keadilan sosial. Kedua, aspek fungsional dari pemerintah yang efektif dan efisien dalam pelaksanaan tugasnya untuk mewujudkan tujuan nasional (Ubaidullah, 2004:113-114). Sisi lain memaknai good governance sebagai penerjemahan kongkrit dari demokrasi.

Tegasnya, menurut E. B. Taylor, good governance adalah pemerintahan demokratis seperti yang dipraktikkan dalam negara-negara demokrasi maju di Eropa Barat dan Amerika misalnya. Demokrasi sebagai suatu sistem pemerintahan dianggap sebagai suatu sistem perintahan yang baik karena paling merefleksikan sifat-sifat good governance yang secara normatif ditunt ut kehadirannya bagi suksesnya suatu bantuan badan-badan dunia. Ia merupakan alternatif dari sistem pemerintahan yang lain seperti totalitarinisme komunis atau militer yang sempat populer di negara-negara dunia ketiga di masa perang dingin.

Konsep governance (tata kelola pemerintahan) merupakan perluasan dari konsep government (pemerintahan), karena di dalam governance terkandung pengertian bahwa pemerintahan (goverment) tidak hanya diselenggarakan oleh pemerintah sendiri, tetapi bersama-sama dengan aktoraktor di luar pemerintah, yaitu masyarakat luas sebagai stakeholders. Dari sinilah adanya anggapan bahwa pemerintah dirasakan tidak memadai dalam menyelesaikan kompleksitas yang ada di masyarakat, sehingga di sinilah letak pentingnya peran good governance untuk membagi otoritas pemerintah dengan masyarakat secara proporsional (Anwar, 2007).

\section{Ciri-Ciri Good Governance}

Dalam dokumen kebijakan United Nation Development Programme (UNDP) lebih jauh menyebutkan ciri-ciri good governance yaitu: 
1. Mengikut sertakan semua, transparansi dan bertanggung jawab, efektif dan adil.

2. Menjamin adanya supremasi hukum.

3. Menjamin bahwa prioritas-prioritas politik, sosial dan ekonomi didasarkan pada konsesus masyarakat.

4. Memperhatikan kepentingan mereka yang paling miskin dan lemah dalam proses pengambilan keputusan menyangkut alokasi sumber daya pembangunan (Hetifa $\mathrm{Sj}, 2003: 3$ ).

Penyelenggaraan pemerintahan yang demokratis saat ini adalah pemerintahan yang menekankan pada pentingnya membangun proses pengambilan keputusan publik yang sensitif terhadap suara-suara komunitas. Artinya, proses pengambilan keputusan bersifat hirarki berubah menjadi pengambilan keputusan dengan adil seluruh stakeholder.

\section{Prinsip-Prinsip Good Governance}

Negara dengan birokrasi pemerintahan dituntut untuk merubah pola pelayanan diri birokratis elitis menjadi birokrasi populis. Di mana sektor swasta sebagai pengelola sumber daya di luar negara dan birokrasi pemerintah pun harus memberikan kontribusi dalam usaha pengelolaan sumber daya yang ada. Penerapan cita good governance pada akhirnya mensyaratkan keterlibatan organisasi masyarakatan sebagai kekuatan penyeimbang Negara. Namun cita good governance kini sudah menjadi bagian sangat serius dalam wacana pengembangan paradigma birokrasi dan pembangunan kedepan. Karena peranan implementasi dari prinsip good governance adalah untuk memberikan mekanisme dan pedoman dalam memberikan keseimbangan bagi para stakeholders dalam memenuhi kepentingannya masing-masing.

Dari berbagai hasil yang dikaji Lembaga Administrasi Negara (LAN) menyimpulkan ada sembilan aspek fundamental dalam perwujudan good governance, yaitu: (Rosyada, 2000: 182).

\section{Partisipasi (Participation)}

Partisipasi antara masyarakat khususnya orang tua terhadap anak-anak mereka dalam proses pendidikan sangatlah dibutuhkan. Karena tanpa 
partisipasi orang tua, pendidik (guru) ataupun supervisor tidak akan mampu bisa mengatasinya. Apalagi melihat dunia sekarang yang semakin rusak yang mana akan membawa pengaruh terhadap anak-anak mereka jika tidak ada pengawasan dari orang tua mereka.

2. Penegakan hukum (Rule Of Low)

Dalam pelaksanaan tidak mungkin dapat berjalan dengan kondusif apabila tidak ada sebuah hukum atau peraturan yang ditegakkan dalam penyelenggaraannya. Aturan-aturan itu berikut sanksinya guna meningkatkan komitmen dari semua pihak untuk mematuhinya. Aturanaturan tersebut dibuat tidak dimaksudkan untuk mengekang kebebasan, melainkan untuk menjaga keberlangsungan pelaksanaan fungsi-fungsi pendidikan dengan seoptimal mungkin.

3. Transparansi (Transparency)

Persoalan pada saat ini adalah kurangnya keterbukaan supervisor kepada para staf-stafnya atas segala hal yang terjadi, di mana salah satu dapat menimbulkan percekcokan antara satu pihak dengan pihak yang lain, sebab manajemen yang kurang transparan. Apalagi harus lebih transparan di berbagai aspek baik di bidang kebijakan, baik di bidang keuangan ataupun bidang-bidang lainnya untuk memajukan kualitas dalam pendidikan.

4. Responsif (Responsiveness)

Salah satu untuk menuju cita good governance adalah responsif, yakni supervisor yang peka, tanggap terhadap persoalan-persoalan yang terjadi di lembaga pendidikan, atasan juga harus bisa memahami kebutuhan masyarakatnya, jangan sampai supervisor menunggu staf-staf menyampaikan keinginan-keinginannya. Supervisor harus bisa menganalisa kebutuhan-kebutuhan mereka, sehingga bisa membuat suatu kebijakan yang strategis guna kepentingan bersama.

5. Konsensus (Consensus Orientation)

Aspek fundamental untuk cita good governance adalah perhatian supervisor dalam melaksanakan tugas-tugasnya adalah pengambilan keputusan secara konsensus, di mana pengambilan keputusan dalam suatu lembaga harus melalui musyawarah dan semaksimal mungkin 
berdasarkan kesepakatan bersama (pencapaian mufakat). Dalam pengambilan keputusan harus dapat memuaskan semua pihak atau sebagian besar pihak juga dapat menarik komitmen komponen-komponen yang ada di lembaga. Sehingga keputusan itu memiliki kekuatan dalam pengambilan keputusan.

6. Kesetaraan dan keadilan (Equity)

Asas kesetaraan dan keadilan ini harus dijunjung tinggi oleh supervisor dan para staf-staf didalam perlakuannya, di mana dalam suatu lembaga pendidikan yang plural baik segi etnik, agama dan budaya akan selalu memicu segala permasalahan yang timbul. Proses pengelolaan supervisor yang baik itu harus memberikan peluang, jujur dan adil. Sehingga tidak ada seorang pun atau para staf yang teraniaya dan tidak memperoleh apa yang menjadi haknya.

7. Efektifitas dan efisien

Efektifitas dan efisien disini berdaya guna dan berhasil guna, efektifitas diukur dengan parameter produk yang dapat menjangkau besarnya kepentingan dari berbagai kelompok. Sedangkan efisien dapat diukur dengan rasionalitasi untuk memenuhi kebutuhan yang ada di lembaga. Di mana efektifitas dan efisien dalam proses pendidikan, akan mampu memberikan kualitas yang memuaskan.

8. Akuntabilitas

Asas akuntabilitas berarti pertanggungjawaban supervisor terhadap stafstafnya, sebab diberikan wewenang dari pemerintah untuk mengurus beberapa urusan dan kepentingan yang ada di lembaga. Setiap supervisor harus mempertanggung jawabkan atas semua kebijakan, perbuatan maupun netralitas sikap-sikap selama bertugas di lembaga.

9. Visi Strategi (Strategic Vision)

Visi strategi adalah pandangan-pandangan strategi untuk menghadapi masa yang akan datang, karena perubahan-perubahan yang akan datang mungkin menjadi perangkap bagi supervisor dalam membuat kebijakankebijakan. Di sinilah diperlukan strategi-strategi jitu untuk menangani perubahan yang ada. 


\section{Good Governance Perspektif Islam}

Para Ahli sebenarnya mengakui bahwa tidak ada struktur pemerintahan terbaik yang dapat diidentifikasi dengan jelas untuk digunakan sebagai model universal bagi negara-negara berkembang (Mishra, 2005). Akan tetapi setidaknya diakui bahwa Good Gavernance adalah suatu kondisi di mana terwujud hubungan tiga unsur yaitu pemerintah, masyarakat atau rakyat dan dunia usaha yang berada di sektor swasta yang sejajar, berkesamaan, dan berkeseimbangan di dalam peran yang saling mengontrol (Mishra, 2005:42).

Bila kita kaitkan dengan syariah, maka apakah hakekat Good Gavernance dalam prespektif hukum Islam? Tidak ada rumusan baku mengenai hal ini. Namun dari berbagai pernyataan yang terpencar di dalam berbagai ayat al-Qur'an maka kita dapat mengkontruksi Good Gavernance menurut prespektif syariah. Di antara ayat tersebut adalah QS Hud : 61 dan QS al-Haj : 41 yang artinya:

"Dia telah menciptakan kamu dari bumi (tanah yang menjqadikan kamu supaya memakmurkannya (membangunnya) [QS. 11:61]. Dan 22: 41...(yaitu) orang-orang yang jika Kami teguhkan kedudukan mereka di muka bumi niscaya mereka mendirikan sembahyang, menunaikan zakat, menyuruh berbuatma'ruf dan mencegah dari perbuatan yang mungkar; dan kepada Allah-lah kembali segala urusan (Q.22:41).

Ayat pertama menjelaskan misi utama manusia adalah membangun bumi. Ayat kedua menegaskan bahwa orang-orang beriman menggunakan kekuasaan yang mereka miliki untuk menegakkan shalat, membayar zakat dan menegakkan amar ma'ruf nahi mungkar (Anwar, 2007:43).

Dari kedua ayat di atas kita dapat merumuskan Good Gavernance dalam prespektif hukum Islam yaitu suatu penggunaan otoritas kekuasaan untuk mengelola pembangunan yang berorientasi pada (1) penciptaan suasana kondusif bagi masyarakat untuk pemenuhan kebutuhan spiritual dan rohaniyahnya sebagaimana disimbolkan penegakan shalat (2) Penciptaan kemakmuran dan kesejahteraan dengan disimbolkan zakat (3) Penciptaan stabilitas politik diilhami dari amar ma'ruf dan nahi mungkar. Singkat kata 
dalam ayat tersebut terdapat tiga governance yaitu: (a) Spiritual Governanace, (b) Economic Governance dan (c) political Governance (Anwar, 2007:44).

Untuk dapat mewujudkan good governance dalam tiga aspek, diperlukan beberapa nilai dan dari nilai-nilai tersebut dapat diturunkan beberapa asas tatakelola pemerintahan yang baik. Dengan memperhatikan ayat-ayat al-Qur'an dan sunnah Nabi saw dapat ditemukan beberapa nilai dasar yang dapat dijabarkan menjadi asas-asas tata kelola pemerintahan yang baik, yaitu: syura, meninggalkan yang tidak bernilai guna, keadilan, tanggung jawab, dan amanah, serta orientasi ke hari depan. Nilai dasar pertama adalah syura yang ditegaskan dalam Q. 3: 159 yang artinya: Dan bermusyawarahlah dengan mereka dalam urusan itu. Dari nilai dasar syura ini dapat diturunkan asas hukum mengenai penyelenggaraan pemerintahan berupa asas partisipasi masyarakat.

Nilai dasar berikutnya dalam hukum Islam adalah penegasan Nabi saw mengenai meninggalkan segala yang tidak bernilai guna, Nabi bersabda, yang artinya: Sebaik-baik Islam seseorang adalah bahwa ia meninggalkan hal-hal yang tidak berguna (HR at-Tirmizi, Ahmad)

Dari hadis ini dapat diturunkan asas efisiensi dalam penyelenggaraan kepentingan publik. Nilai dasar lain dalam hukum Islam adalah keadilan. Penegasan mengenai keadilan dalam sumber-sumber Islam banyak sekali, misalnya dalam Q. 5: 8 yang artinya: Berbuat adillah kamu, (karena) berbuat adil itu lebih dekat kepada taqwa (Q. 5: 8).

Masalah keadilan secara umum dan masalah kepastian hukum merupakan jeritan seluruh masyarakat Indonesia saat ini. Tata kelola pemerintahan yang baik menghendaki adanya jaminan kesamaan akses seluruh warga masyarakat terhadap sumberdaya politik, ekonomi, dan administratif.

Tanggung jawab sebagai nilai dasar syariah dapat diturunkan asas responsivitas dalam pemberian pelayanan. Secara khusus asas ini dapat pula disimpulkan dari firman Allah yang menggambarkan pribadi Rasulullah saw yang sensitif terhadap penderitaan umatnya, (Q. 9: 128):

"Telah dating kepadamu seorang utusan (rasul) dari kalanganmu sendiri, berat dirasakannya apa yang kamu derita, sangat memperhati- 
kan kamu dan amat belas kasih lagi penyayang terhadap orang-orang mukmin" (Q. 9: 128)

Responsivitas adalah kemampuan untuk mengenali kebutuhan masyarakat, menyusun agenda dan prioritas pelayanan, serta merencanakan program-program pelayanan yang dibutuhkan masyarakat. Selain itu nilai dasar hukum Islam lainnya adalah amanah. Di dalam konsep amanah itu terdapat suatu asas akuntabilitas. Dalam hal ini, al-Qur'an menegaskan (Q. 2: 42) yang artinya: Dan janganlah kamu menyembunyikan kebenaran, padahal kamu mengetahui (Q. 2: 42).

Salah satu pengertian yang dapat ditarik dari keumuman pernyataan ayat ini adalah adanya asas transparansi termasuk di dalam transparansi dalam penyelenggaraan birokrasi untuk pelayanan publik. Akuntabilitas dan transparansi adalah kriteria lainnya yang penting dalam suatu good governance.

Nilai dasar lainnya dalam ajaran dan hukum Islam adalah orientasi ke hari depan. Islam sangat menekankan kepada umatnya agar mereka memperhatikan hari esok dan membuat perencanaan dan persiapan untuk menghadapi hari depan. Di dalam al-Qur'an ditegaskan: ...dan hendaklah setiap orang memperhatikan apa yang dipersiapkan untuk hari esok (Q. 59: 18).

Dalam Islam diajarkan dua macam hari depan, yaitu akhirat dan hari esok, diajarkan pula dalam Islam bahwa hari depan itu harus lebih baik dari hari ini. Dalam al-Qur'an terdapat isyarat-isyarat mengenai hal itu seperti dalam Q. 93: 3-4

Artinya: tiadalah tuhanmu meninggalkan kamu dan tidak pula dia membencimu; dan sesungguhnya hari esok adalah lebih baik bagimu dari hari yang telah lalu (Q. 93: 3-4)

Keseluruhan kutipan diatas menjelaskan keharusan adanya visi yang jelas dalam hidup setiap orang (Anwar, 2007: 44-45). Dari penjelasan di atas maka dapat disimpulkan bahwa good governance: 

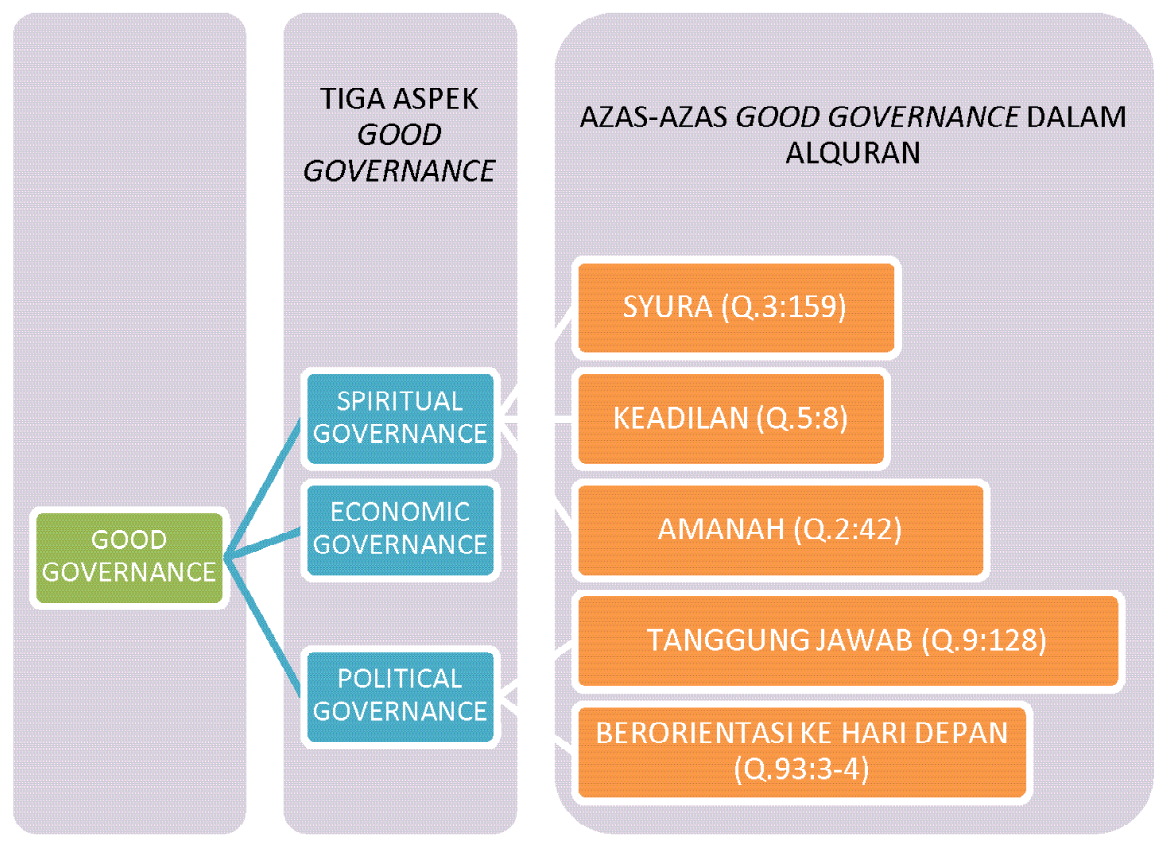

Sumber: Informasi yang diolah

\section{Penutup}

Pendekatan ushul fiqh dengan menggunakan teori pertingkatan norma sangat penting untuk didalami dan diterapkan pada kasus-kasus yang populer seperti era sekarang ini. Melihat banyaknya permasalahan, terutama kurang bagusnya tata kelola pemerintah, memberikan peluang untuk mengkaji fenomena ini. Kajian good governance menjadi kontribusi tersendiri bagi pengembangan tata kelola birokrasi yang lebih baik sesuai dengan prinsip dan nilai-nilai dalam hukum Islam seperti nilai kesetaraan, tasâmuh (toleransi), keadilan (justice), kemaslahatan, musyawarah (syûrâ), kejujuran (honesty), objektif (comprehensiveness), meninggalkan yang tidak bernilai guna, tanggung jawab dan amanah, serta orientasi ke hari depan dan seterusnya menjadi indikasi terbentuknya pemerintahan yang bersih dan baik (good and clean governance). 


\section{Daftar Pustaka}

Abdullah, Amin. 2004. Pendekatan Hermeneutik dalam Studi Fatwa-Fatwa Keagamaan: Proses Negosiasi Komunitas Pencari Makna Teks, Pengarang, dan Pembaca", dalam Pengantar buku Khaled M. Abou El-Fadl, Atas Nama Tuhan dari Fikih Otoriter ke Fikih Otoritatif, Jakarta: Serambi.

Ahmad al-Jarjani, Ali.Hikmatu at-Tasyrì' Wa Falsafatuhū, Libanon: Dār alFikr, t.t..

Anwar, Syamsul. 2007. Studi Hukum Islam Kontemporer, Jakarta: RM Books.

Anwar, Syamsul.2002. "Pengembangan Metode Penelitian Hukum Islam", dalam Ainurrafiq (ed.), Mazhab Jogja: Menggagas Paradigma Ushul Fiqh Kontemporer Yogyakarta: Ar-Ruzz, 2002.

Anwar, Syamsul. 2004. "Pengembangan Metode Penelitian Hukum Islam dalam Riyanta (ed.), Neo Ushul Fiqh: Menuju Ijtihad Kontekstual, Yogyakarta: Fakultas Syariah Press.

Hetifa Sj, Sumarto. 2003. Inovasi, Partisipasi dan Good Governance, Bandung: Yayasan Obor Indonesia.

Hikam, Atoillah Shohibul. 1998. Demokrasi dan Civil Society, Jakarta: LP3ES.

Mishra, Satish Candra. "Pemerintah dan Pemerintahan: Memahami Ekonomi Politik Reformasi Institusi” Jurnal Reformasi Ekonomi, Vol 1 (2)

Ramadhan al-Buty, Sa'id. 1992. Dawabit al-Maslahah fial-Shari'ah alIslamiyyah, Beirut: Mu'assasat al-Risalah.

Rosyada, Dede. 2000. Demokrasi, Hak Asasi Manusia Dan Masyarakat Madani, Jakarta: ICCE UIN Syarif Hidayatullah.

Sudarmayanti. 2004. Good Governance II, Bandung: Mandar Maju.

Suraji, Imam. 2011. Good Governance (Kepemimpinan di Tengah Perubahan), Jurnal Hukum Islam, Vol. 15 (1):70.

Syarifuddin, Amir. 1992. Pengertian dan Sumber Hukum Islam, Jakarta: Bumi Aksara.

Syarifuddin, Amir.2009.Ushul Fiqh, Jakarta: Kencana.

Thoha. 2003.Birokrasi dan Politik Indonesia, Jakarta: PT. RajaGrafindo Persada.

Wael B, Hallaq. 2004.Authority, Continuity, and Change in Islamic Law, New York: Cambridge University Press 2004. 